\title{
The water quality of streams located in large urban agglomeration, case study of the Służewiecki Stream
}

\author{
Małgorzata Wojtkowska ${ }^{1, *}$, Magdalena Matula ${ }^{1}$, and Paulina Kozińska ${ }^{1}$ \\ ${ }^{1}$ The Faculty of Building Services, Hydro and Environmental Engineering, the Warsaw University of \\ Technology, 00-653 Warszawa, Poland
}

\begin{abstract}
The quality assessment of watercourse, located in a highly urbanized area was the goal of research. The Służewiecki Stream, which flows in the southern part of the capital city of Warsaw is the subject of study. The aim of the research was to determine the tendency of the water quality changes in the Służewiecki Stream, flowing in the highly urbanized area and being a sink of the non-point and industry sources of pollutions as well as the surface runoffs which comes from its catchment. The field research was conducted along the entire length of the stream in 2015 and 2016. The water samples were collected monthly from a depth to $20 \mathrm{~cm}$. Water quality tests were carried out in accordance with the valid analytical methods. The obtained results point to poor water quality. Therefore it can be conducted that the development and use of the direct catchment is the one of main factors affecting the water quality in Służewiecki Stream. The tributaries, often not inventoried, from built-up, populated areas, are the most polluted. Tributaries contain large amount of organic compounds and nutrients.
\end{abstract}

\section{Introduction}

Concern about the quality of the aquatic environment is a priority task of modern society [1]. In the time of intensifying urban transformations and intensive development activity, the protection of surface waters becomes important. The urbanization of the areas directly adjacent to watercourses significantly affects the water quality. A human activity increase causes changes in the land cover structure, therefore the possibility of water in rivers and streams degeneration $[2,3]$.

Pollution from the surface runoffs and treated or partially treated sewage, introduced into rivers and streams or canals, is transported along with water flow and affect their quality [4, 5]. The water pollution from the industry was reported in many countries in Africa, such as Lesotho [6] and Ghana [7]. The changes in land use connected with population growth revealed the sensitivity of water in various catchments. A positive correlation between the population density and deterioration in water quality was found along the Bagmati river in Nepal [8]. Removal of natural vegetation and transformation of land use into urban areas,

\footnotetext{
* Corresponding author: malgorzata.wojtkowska@pw.edu.pl
} 
results in increasing of runoffs thus facilitates the transport of pollution from ground to watercourses [9].

The changes in water quality are usually associated with processes which took place in the water column. The transport of pollutants in turbulent water flow assumes simultaneously occurrence of carried (advection), turbulent and molecular diffusion. The mixing of pollution, as a result of these processes, takes place until the pollution will spread on the entire crosssectional area of the water stream. Therefore the concentration of pollution is aligned in whole water volume. In accordance with Directive 2008/105/EC of the European Parliament and the Council [10], which imposes an obligation to designate areas beyond which the environmental quality standards will be met, the practical estimation of the length of the complete mixing zone is needed.

Considerable water contamination with organic compounds and nutrients leads to substantial degeneration of watercourses and reservoirs [11]. The effects of this degeneration are observed by changes in the colour of water and appearance of unpleasant smell. The creation of foam on the water surface is a possible effect of decomposition of organic substances and elevated concentrations of nitrogen and phosphorus compounds. This kind of phenomenon was observed on the surface of Wilanowskie lake, at the mouth of the Służewiecki stream in March 2016 [12].

The enrichment of water in many forms of chemical compounds is caused by the inflow of pollutants from direct catchment [13]. The changes in land use, development and management of the catchment have a vital impact on the quantity and quality of surface waters. The inflow of pollutant loads may causes consequences in the nature of the ecosystem [14].

\section{The general characteristics of the Służewiecki Stream}

The catchment of Służewiecki Stream is located in the Vistula basin, in the southern part of Warsaw and covers the following districts: Ochota, Włochy, Ursynów, Wilanów. The first section of the Stream is the covered drainage, up to the intersection of Hynka and Radarowa Streets, where the first rainwater collector is drained into Stream. Below Hynka Street the Stream passes into open drainage to the border of Chopin Airport. The next rainwater collector (here, rainwater is collected from the area of Okęcie Przemysłowe - the industrial part of Okęcie district) is joined to the Stream before the Airport. Then they flow under the airport apron and appear nearby Wirażowa Street. From the outflow near Wirażowa Street up to the mouth into Wilanówka river the Stream flows as open riverbed, with few places with baffles, like culverts. The main tributaries, below the airport, are the open ditches. The Służewiecki Stream also joins some storm water drainages, which drain rainwater from Stream catchment. The biggest tributary is Grabowski ditch [15]. All of them provide the necessary amount of water for preservation of biological life in further section of Stream, which virtually has not his own source. Then the Służewiecki Stream flows to Wilanów district, where it flows through the Wilanowskie Lake and Sobieskiego Canal into the Wilanówka river. The entire catchment area is located within the administrative boundaries of the Capital City of Warsaw. Stream ends in the area of the royal palace and garden complex in Wilanów. In 1998 Służewiecki Stream was considered by State Inspectorate of Environmental Protection (PIOŚ) as surface watercourse [16]. At present the total length of Stream is about $15 \mathrm{~km}[17]$. 


\section{Materials and methods}

Służewiecki Stream was selected for the study. According to regulation of the Minister of the Environment of 9 November 2011 on status classification of surface water bodies and environmental quality standards for priority substances, Official Journal of the Laws of 2011, No. 257, Item 1545 [18] (hereinafter referred to as the Regulation), this watercourse was classified as "watercourse in the valley of a large lowland river - code 26 ".

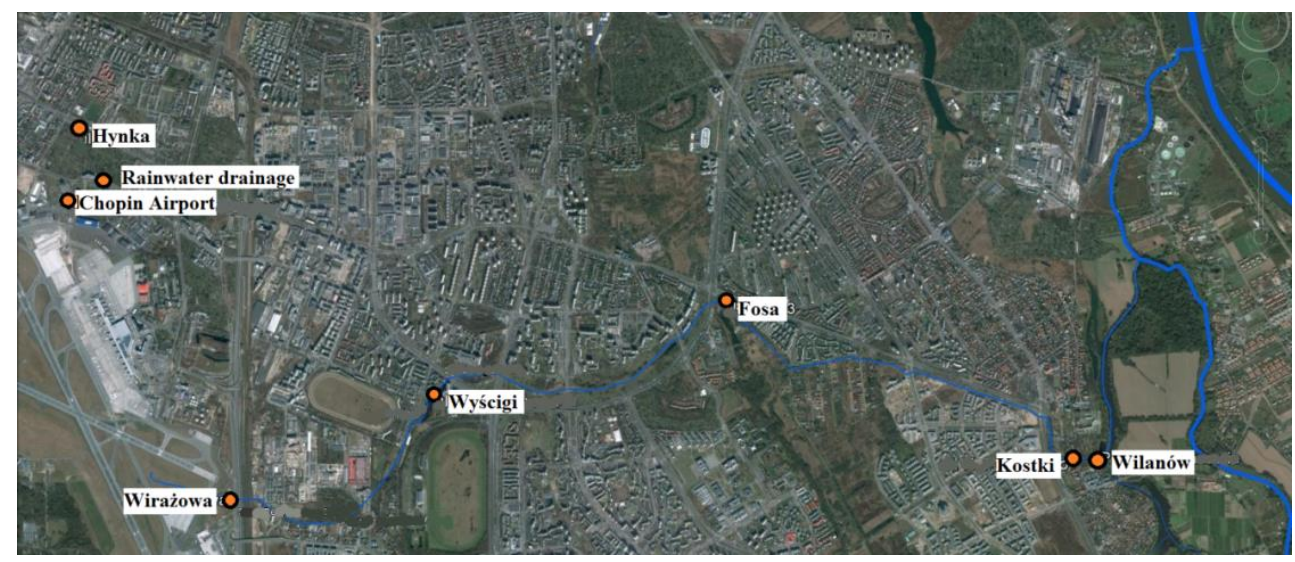

Fig. 1. The location of sampling sites in the Służewiecki Stream.

The research was systemically conducted all over the year in monthly intervals. To analyze the status of the flowing water quality in Stream, for the purpose of this study, the surface water samples were collected from August 2015 to July 2016. The eight sampling sites were selected for this monitoring (Fig. 1):

1 (Hynka) - near Hynka Street, the entrance to allotment gardens from the 17 Stycznia Street side and on (about $500 \mathrm{~m}$ behind the gate);

2 (Rainwater drainage) - rainwater drainage in 17 Stycznia Street pavement;

3 (Chopin Airport) - the Chopin Airport area - flow control chamber 1 (first sewage well from 17 Stycznia Street);

4 (Wirażowa) - Wirażowa Street, outflow from the Chopin's Airport;

5 (Wyścigi) -Wyścigowa Street 14, by the bridge;

6 (Fosa) - Fosa Street 3, by the bridge;

7 (Kostki) - Kostki Potockiego Street, by the bridge;

8 (Wilanów) - before the mouth of the Streem into Wilanowskie Lake, below the cascade.

In 2015 the water samples were collected from seven sites, except for the site number 2 (rainwater drainage in 17 Stycznia Street pavement), whereas in 2016 on the site number 2 the samples were collected from March to July. In June 2016 the sample from the allotment gardens was once additionally collected.

The scope of the analysis, which were made on the water samples, includes: physicochemical indicators of water quality, the indicators of substances particularly hazardous to the aquatic environment (the specific synthetic and non-synthetic pollutants) and those from the list of priority substances as well as other pollutants referring to water bodies of all categories. The interpretation of the results of measurements on water quality indicators was carried out in accordance with (valid during the research) version of the Regulation from section "The limit values of water quality indicators, referring to surface water bodies in natural watercourses like: tributary, creek, stream, ditch and river, not designated as unnatural or heavily modified water bodies. The analytical scope included 24 physicochemical indicators and 15 chemical indicators from the list of priority substances. 
In this study the groups of physicochemical indicators, which support the biological indicators, were selected groups of indicators which characterized:

- physical status - the water temperature, total suspended matters;

- oxygen conditions and organic compounds concentration - dissolved oxygen, BOD, COD and TOC;

- the salinity - conductivity, chloride, calcium, total water hardness,

- the acidity $-\mathrm{pH}$,

- the nutrients status - the ammoniacal nitrogen, the Kjeldahl nitrogen (Norg $+\mathrm{N}_{-} \mathrm{NH}_{4}^{+}$), nitrate nitrogen, the total nitrogen, the total phosphorus.

From the group of indicators of substances particularly hazardous to the aquatic environment (the specific synthetic and non-synthetic pollutants) according to annex no. 4 to the Regulation, the following indicators were measured: metals (arsenic, boron, chromium, nickel, lead, mercury), octylphenol and nonylphenol.

In addition to the listed indicators from the Regulation, the analysis was extended to: colour, smell, the nitrite nitrogen, potassium, sodium, surfactants - anionic and non-ionic, the mineral oil index, substances extracted with petroleum ether, manganese and iron.

\section{Results}

The following results point to fluctuations in water quality at selected sites. The water was highly mineralized due to high conductivity and chloride concentration. In 2015 the strongest contamination was found from the site no. 1 - Hynka Street to site no. 4 -Wirażowa Street (Fig. 1). On few first sites the water had alkaline character. The samples were significantly salted - on numerous sites high values of conductivity were recognized - for example on site no. 1 from 684.8 to $4000 \mu \mathrm{S} / \mathrm{cm}$ (Fig. 2).

The highest concentrations were found in winter season, from the December 2015 to March 2016. At that time the concentration of chlorides in water at the same sites reached the highest values, in December to $739 \mathrm{mg} / \mathrm{l}$ and from January to March in the range of 198 to $1000 \mathrm{mg} / \mathrm{l}$.

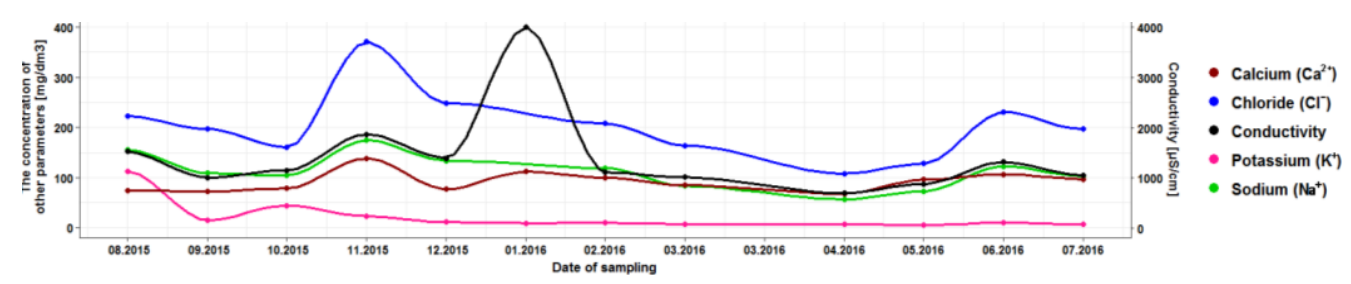

Fig. 2. Changes in the concentration of salinity indicators in relation to the time at Hynka Street.

At the first four sites the poor water quality resulted from the high concentrations of BOD, COD and TOC. These indicators classified the water from Służewiecki Stream, at almost all collection dates, beyond the second class of surface water quality. The highest concentrations of organic pollutants (BOD, COD, TOC) were obtained at the sites from the Hynka to Wirażowa Street (Fig. 1). On the first site (Hynka Street) were found the high values of BOD were found (up to $16 \mathrm{mg} \mathrm{O}_{2} / \mathrm{l}$ ) therefore the water incoming to the airport area was already significantly polluted.

At the further few sites most of obtained values point to improvement of water quality thus classifying it to first or second water quality class according to the Regulation. On the further section of stream, behind the Wirażowa Street, the BOD was in most dates decreased as well as other concentrations of organic compounds (Fig. 3). The periodic increase of 
organic compounds in these parts of Stream was attributed to the presence of pollutant sources.

At the first sites (Hynka Street, an airport area) there were found high concentrations of substances (ammoniacal nitrogen, Kjeldahl nitrogen, total nitrogen and total phosphorus) which cause the water eutrophication (Fig. 3). The high concentrations of nonionic surfactants were also found on these sites.

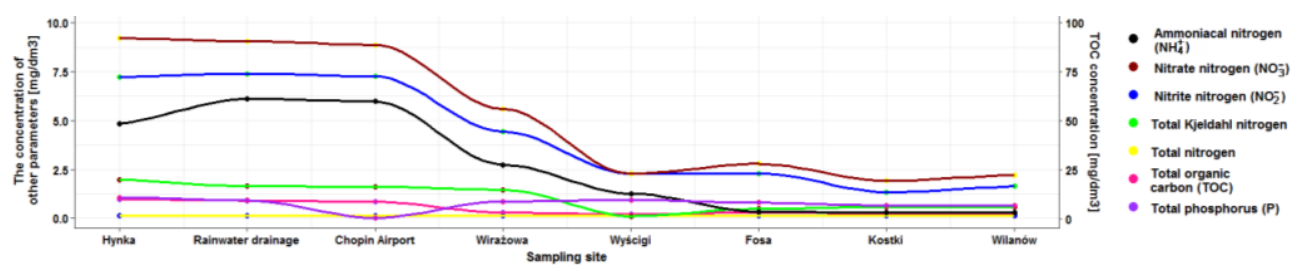

Fig. 3. Changes in the concentration of nutrients at particular sites in June 15, 2016.

At sites located further, from the Wyścigowa Street to Wilanów (Fig. 1), the water had good quality status in 2015. In this part of Służewiecki Stream the water was much cleaner due to the lower values of salinity and nutrients indicators. Only periodically the elevated values of conductivity, oxygen indicators (BOD, COD) and total phosphorus were observed, which classified water up to the second class of surface water quality.

Analyzing the indicators values of water quality from January to August 2016 it can be seen that the water in most of the dates, at all sites, was still highly contaminated with organic substances due to the high values of BOD and COD indicators (Fig. 4).

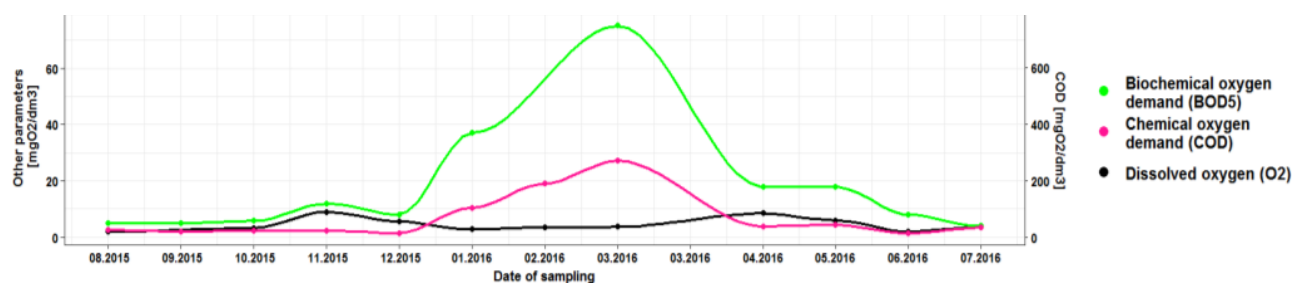

Fig. 4. Change in the concentrations of oxygen indicators during the research period at Wyścigi.

Also the values of nutrients and salinity indicators were increased in the mentioned period (Fig. 5 and 6).

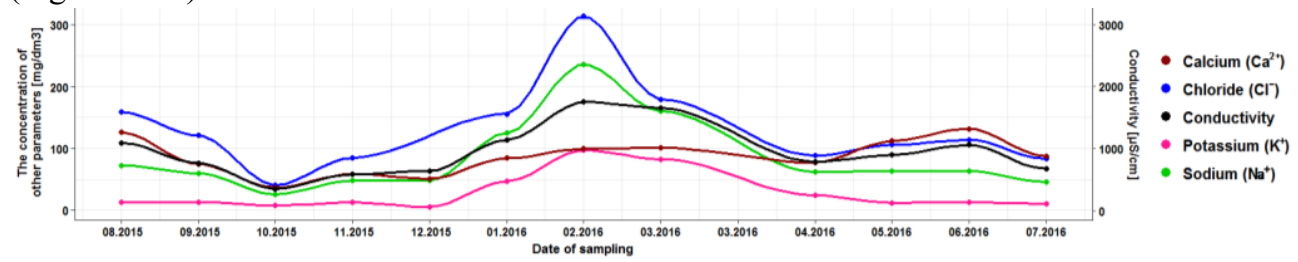

Fig. 5. Changes in the concentration of salinity indicators in relation to the time at Wyścigi.

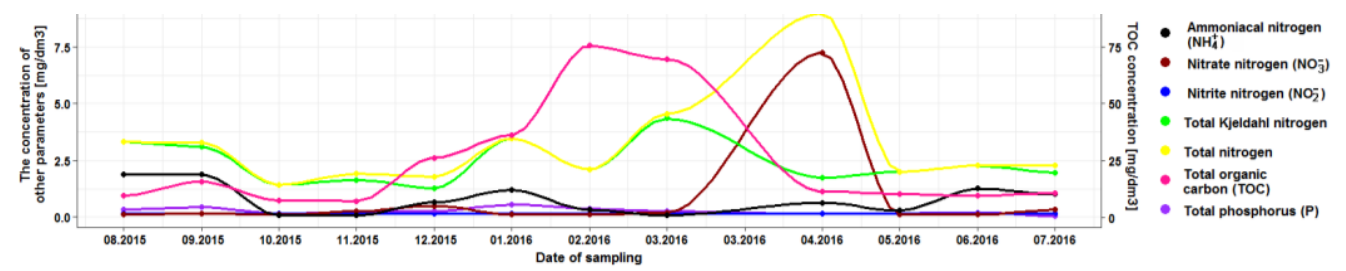

Fig. 6. Change in the value of nutrients indicators during the research period at Wyścigi. 
In 2016 as well as 2015 the highest concentrations of pollutants were observed on sites from Hynka to Wirażowa Street (Fig. 7). The water collected from the sites 6 to 8 was of better quality. Although since April also high values of oxygen status indicators were observed. Since March in samples collected from sites near Fosa and Kostki Potockiego Street the concentrations of nutrients indicators classified water mostly to the first class of quality. In the water collected from the last site, located before the mouth of Służewiecki stream into Wilanowskie lake, there were found higher concentrations of organic substances and the Kjeldahl nitrogen, which classified this water beyond the second class of surface water quality.

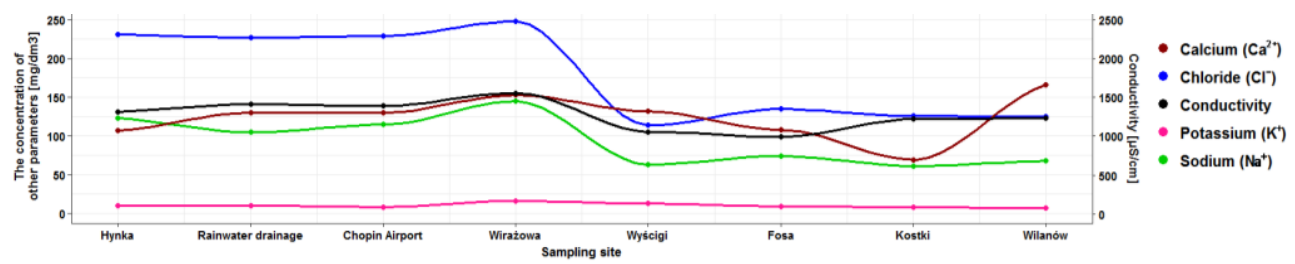

Fig. 7. Changes in the concentration of salinity indicators at particular sites in June 15, 2016.

The concentrations of phosphorus compounds was lower and classified water, in winter, to second and in spring season to first class of surface water quality. In February, March, June and August the water quality improved, probably due to their dilution from side tributaries. The results described above indicate the need for assessment of the water quality in Służewiecki Stream in its specific cross-sections, taking into account the quality status of the water flows through its bed in earlier sections of the watercourse.

In 2016 the analytical scope was extended by the: concentrations of metals and the organic compounds indicators (phenols and substances extracted with petroleum ether). Periodically, on the sites from 1 to 5, high concentrations of harmful metals (cadmium, nickel, lead) appeared in the water. It should also be noted that during this period in water were also found the petroleum substances measured as substances extracted with petroleum ether. The highest concentrations of these substances were found in May, at all of the sites. Furthermore, in June and July their concentrations were much lower.

\section{Discussion}

The analysis of obtained results led to evaluation of the quality status of the Służewiecki Stream and interpretation of the changes taking place in water of Stream due to the ecological risk. The results confirm the influence on the water from: surface runoffs, meltwater from streets, tributaries which contain sewage from adjacent industrials areas and the rain drainage water. The effects of the anthropogenic impact on the flowing water quality in urban areas were also found by other researchers [19, 20].Using salt for winter road maintenance (the area of Aleja Krakowska and 17 Stycznia Street) in the winter season causes the inflows of highly saline meltwater to the Służewiecki Stream, therefore the high chlorides concentration in the Stream.

The obtained values of water temperatures and $\mathrm{pH}$ classify the waters from Stream, in the entire considered period and at all of the sampling sites, to the first class of surface water quality. Both of mentioned parameters determine many chemical and biochemical processes in water, hence it is important to consider them during the interpretation of other water quality parameters. The factors affecting the concentrations of pollutants in Służewiecki Stream may be: the low water level, slow flow, high water temperature and the accelerated oxygen consumption caused by the decomposing organic substances and oxidizing mineral compounds. 
The oxygen conditions, organic and nutrients pollution as well as salinity and acidification are responsible for low water quality in Służewiecki Stream (according to Regulation - beyond the second class of surface water quality). The nutrients indicators have the vital impact on the water quality in Stream. The concentrations of total nitrogen and phosphorus exceeded values which characterize second class of water quality. During the sampling cycles the highest concentrations for this indicators were found at first site. In the matter of fact, the Stream before the airport area was often more contaminated compared to the section of Stream from the site no. 4 (Wirażowa Street) to the mouth of Stream. The high concentrations of the ammoniacal nitrogen, which were also noticed, are the reason of the oxygen consumption in the oxidation process to nitrate nitrogen [21]. The increase in the concentration of nitrate nitrogen affects the biomass expansion, hence water eutrophication and further reduction of the dissolved oxygen concentration. Observed oxygen deficits create the unfavorable conditions for the water biocenosis, both in Służewiecki Stream and in Wilanowskie Lake.

The chemical and biochemical oxidation processes and flow velocity have also significant influence on the content of the oxygen in surface water.

The water in Służewiecki Stream during the measurements period was characterized by good and very good values of the oxygen at most times and sampling sites according to the Regulation. However, the deficit or overload of oxygen in water periodically occurred. The high concentrations of dissolved oxygen may occur as a result of intensive photosynthesis process, resulting in biomass growth. In the water of Służewiecki Stream there were found high concentrations of organic compounds, both biodegradable (BOD) and barely biodegradable (COD). As a result of the processes of decomposition of organic substances, the dissolved oxygen in water is consumed. The ongoing reduction process can be connected with unpleased smell coming from the presence of: methane, hydrogen sulphide and ammonia. These gases are the products of decomposition of organic matter present in water and bottom sediments. It should be emphasized that the decomposition of organic substances of the high proteins content (presence of TOC and Kjeldahl nitrogen) and phosphates, may cause the low concentrations of oxygen in water thus the presence of foam on the water surface, for example near the mouth of Stream, below the cascade. The obtained values of nutrients indicators were similar to those investigated in the Lyna River [22], but much more lower than in results of studies of Kazi et al. (2009) of the Manchar Lake [23].

Such phenomena were observed before the mouth of Służewiecki Stream to the Wilanowskie lake, where the thick layer of foam appeared. The research points to the periodic inflow of petroleum substances and surfactants to the Stream. The presence of mentioned substances would also contribute to reducing the dissolved oxygen concentration in water. The degradation of petroleum substances, which are floating on surface layers of water, often leads to photochemical processes. As a result of this chemical reaction, the fatty acids may appear and then react with alkali metals that stay in normal, geochemical range and subsequently form the salts with surface-active properties. This process can also cause foam production on the water surface [24].

\section{Conclusions}

The conducted analysis of the research results on most of the sampling dates and along the entire length of the watercourse, indicates low water quality of the Służewiecki Stream. Lower concentrations were observed in the results from the 2015 and only at sites from the Fosa Street to the Wilanów. On the basis of obtained data it can be concluded that the low water quality is caused by rain and meltwaters from the adjacent areas. The large load of both the organic and mineral compounds which come from chemicals used for de-icing communication surfaces, particularly in winter, is observed. The significant levels of 
pollution were most frequently observed simultaneously throughout the entire considered part of the Stream. Along the course of water it can be observed that the reduction of the pollution level is shifted in time. However, the self-purification process is slow and water with large load of pollution finally flows to the Wilanowskie Lake. The rainwaters and metlwaters from the area of Stream catchment should be drained to the municipal sanitary sewage system to improve the water quality in Służewiecki Stream and consequently in the Wilanowskie Lake. It is required to continuously monitor the indicators of mineral (conductivity, chlorides), organic (BOD, COD, TOC) and nutrients pollution (Kjeldahl nitrogen, total phosphorus), regarding the inflow of rainwaters and meltwaters. The goal of proposed monitoring is the unambiguous assessment that the pollutants from the adjacent industrial areas are the reason of low water quality in Służewiecki Stream and cause the processes which effects are observed in Wilanowskie Lake (e.g. foam forming).

\section{References}

1. Directive 2000/60/EC of the Eur. Parl. and of the Council, OJ L 327, 1-73 (2000)

2. E. Ngoye, J.F. Machiwa, Phys. Chem. Earth 29, 1161-1166 (2004)

3. L. Sliva, D.D. Williams, Water Res. 35, 3462-3472 (2001)

4. J. Kubiak, A. Tórz, Słupskie Prace Biol. 2, 17-36 (2005)

5. M. Wojtkowska, Gaz Woda Tech. 11, 70-73 (2006)

6. D. Pullanikkatil, K. Urama, IJEE 3, 175-191 (2011)

7. E.M. Attua, J. Ayamga, O. Pabi, JRBM 12, 57-68 (2014)

8. M.P. Bhatt, W.H. McDowell, K.H. Gardner, J. Hart, Env. Earth Sci. 1, 911-922 (2014)

9. C.L. Arnold, C.J. Gibbons, JAPA 62, 243-258 (1996)

10. Directive 2008/105/EC of the Eur. Parl. and of the Council, OJ L 348, 84-97 (2008)

11. M. Wojtkowska, D. Dmochowski, Environ. Prot. Eng. 35, 57-66 (2009)

12. https://iwilanow.pl/artykul/na-jeziorze-wilanowskim-znow-pojawila-sie-piana-zrodlozanieczyszczenia-dalej-nieznane/42210 (30.03.2016, access: 29.01.2018)

13. M. Kornaś, A. Grześkowiak, Woda Środ. Obsz. Wiej. 11, 125-137 (2011)

14. D. Bedla, K. Król, Acta Sci. Pol. Formatio Circumiectus 13, 25-33 (2014)

15. K. Wawer, Synteza problemów wodno-gospodarczych w zlewni jeziora Wilanowskiego i rzeki Wilanówki (Warszawa, 2014)

16. Z. Biernacki, Geomorfologia i wody powierzchniowe, in: Wisła w Warszawie (Dom Wydawniczy ELIPSA, 22-70, 2000)

17. M. Wojtkowska, E. Karwowska, I. Chmielewska, K. Wawer, IJERA 6, 12-15 (2016)

18. Regulation of the Min. of the Envir. of 9 November 2011, OJ L 257, Item 1545 (2011)

19. A. Potasznik, S.Szymczyk, J. of Elementology 20, 3, 677-692 (2015)

20. M.A. Mallin, V.L. Johnson, S.H. Ensign, Env. Monit.and Ass. 159, 475-491 (2016)

21. O.T. Dede, I.T. Telci, M.M. Aral, Wat. Qual., Expos. and Health 5, 1, 41-56 (2013)

22. K. Glińska-Lewczuk, I. Gołaś, J. Koc, A. Gotkowska-Płachta, M. Harnisz, A. Rochwerger, Environ. Monit. Assess. 188, 624 (2016)

23. T.G. Kazi , M.B. Arain, M.K. Jamali, N. Jalbani, H.I. Afridi, R.A. Sarfraz, J.A. Baig, Abdul Q. Shah, Ecotox. and Env. Safety 72, 301-309 (2009)

24. D.E. Nicodem, M. Conceicao. Z. Fernandes, C.L.B. Guedes, R.J. Correa, Biogeochemistry 39, 121-138 (1997) 